\title{
An Investigation on Utilization of Internet and Television in Senior Secondary Schools in Rigachukun Inspectorate of Kaduna State in Nigeria
}

\author{
O.K. Fadele ${ }^{1 *}$; S. Haruna ${ }^{2}$; T.O. Amusan ${ }^{3}$; S.A. Olumuyiwa ${ }^{4}$ and N.E. Onwuegbunam ${ }^{4}$ \\ ${ }^{1}$ Department of Agricultural Engineering, Federal College of Forestry Mechanization Afaka Kaduna \\ Forestry Research Institute of Nigeria. \\ ${ }^{2}$ Department of Education Technical, Kaduna Polytechnic, Kaduna Nigeria. \\ ${ }^{3}$ General Studies Department, Air Force Institute of Technology. \\ ${ }^{4}$ Basic Science and General Studies Department, Federal College of Forestry Mechanization Afaka \\ Kaduna Forestry Research Institute of Nigeria. \\ ( ${ }^{*}$ Corresponding author’s email and phone no: fadeleseyi@yahoo.com, 2348064487957)
}

\begin{abstract}
An investigation was carried out to study the effects of television and internet on academic performance of senior secondary schools students in Rigachukun Inspectorate of Kaduna state. A well structured and designed questionnaire was adopted in eliciting information from the respondents. The respondents were sampled from schools within Kaduna state. The information obtained showed that the percentage of senior secondary school students who made use of internet for academic purpose was as much as those who could not operate a computer or even browse the internet. Good number of students applied internet mostly through phones and computer with internet access in solving their assignment. A larger percentage of students devoted their time to watching non-educative programs on television, even though it was discovered that some of them also watch educative programs. Positive impacts of television and internet are however obscuring and not glaring. Investigation carried out revealed that students in senior secondary schools need to be sensitized and oriented on how they can derive the best from internet and television. Schools should be encouraged in using television and internet as an instrument of learning and teaching.
\end{abstract}

\section{Keywords: Internet, Television, academic performance, utilization.}




\subsection{INTRODUCTION}

Television also known telly or TV set is an electronic device used for broadcasting visual images of stationary or moving objects displayed through the screen while internet is a global network of computers which aims at providing diverse kinds of information and communication facilities. The Internet is a global network of computers linked together over large distances. It was created by the American Military as a means of communication and has been in existence since the 1950's (Osunade, 2003; Fadele, 2011). Internet is the most recent device of knowledge acquisition tool. Information received through the internet could be visual usually involving moving objects as well as facts in form of text. The influence of television and internet on education is a very critical issue that needs to be attended to. These two facilities have been used in promoting and enhancing education. Television and internet have proven to be indispensable device that can be used to develop cognitive skill of students. Television and internet electronic media classified under information and communication technologies. It has been asserted in some high institution of learning that internet browsing improves the academic performance of students. It also serves as a useful tool for teachers in helping to prepare lesson plans and researchers in getting information on relevant subjects (Osunade, 2003; Brown and Marin, 2009).

However, the negative effect of television and internet on academic performance of students generally has become an issue of great concern to the society at large. It has been established by most key players in educational circle that television and internet are detrimental to students' performance in school. Recent researches conducted revealed that most students spend good number of hours watching programmes that are not educational as well abusing internet facilities by constantly chatting on websites such as face book, yahoo messenger and twitter to mention but few (Subrahmanyam et. al., 2000). The ubiquitous presence of television in every 
home most countries whether developed or developing has made the matter worse; it is quite obvious that most school boys spend their time watching football match especially the foreign league. It has reached a level where they even pay through their nose to watch these match in television viewing centre, especially in a situation where they can't get access to a television. The girls are not left behind, as they engage themselves in watching movies on satellite stations.

Moreover, many researchers have worked on effects of television and internet in most developed countries, focusing on their negative or positive influence with little being done in the developing countries (Kondo and Steemers, 2007). Having delved for information on how internet and television affect academic performance of senior secondary school in Kaduna, Nigeria; none was found. This brought about this subject. Kaduna being central in the northern part of Nigeria would give a good representative of what is obtainable in the other states located in this region. The objective of this study is to carry out investigation on the effects of television and internet on students' performance in senior secondary schools in Kaduna inspectorate.

\subsection{METHODOLOGY}

This section discussed the methodology used in carrying out the research using the following as sub-headings:

\subsection{Research Design}

In the conduct of this research a questionnaire was prepared to collect information on the areas examined. The questionnaire has three sections which are the background information, television impact and internet impact. The questionnaire was administered in schools within Rigachikun Inspectorate division of Kaduna State. The questionnaires were given to the students 
through their teachers and school heads. The descriptive statistical analysis was adopted in treatment of data collected.

\subsection{Area of the Study}

The study covered - selected secondary schools in Rigachikun Inspectorate division. The schools were selected because they are among the largest and recognized schools within the division. A total of 121 respondents were randomly sampled and given questionnaires to respond to. Only students in the senior secondary school were considered for this research. The research was limited to the students in higher classes because it is believed that they are more exposed to media facilities. They also have more liberty over these facilities compared to students in lower classes. The respondents consist of 62 art students, 2 technical students, 55 science students and the remaining 4 were invalid. The Igabi local government of Kaduna State Nigeria was considered for the research and some secondary schools were sampled out for questionnaire administration. The sampling was done randomly without any form of preference for a particular school.

\subsection{Instrument Used for the Study}

The instrument for data collection was a well designed questionnaire. It was formulated in such a way as to capture all the necessary information regarding this research from the students. The questionnaires were administered to the students in all the schools considered for the research. Each copy of the questionnaire consists of four sections with 33 items spread within the four sections. Section A was concerned with personal data of the respondents and contains 6 items. Section B elicits information on television impacts from the respondents and contains 10 items. Section C considers internet impacts and contains 13 items. Section D assess students' performance and contains 4 items. 
Experience educationists were consulted in the course of planning and administration of the questionnaires. The questionnaire was considered appropriate and valid for the conduct of this research. The instrument was formulated in line with suggestions and advice given by the educationist before the administration of the questionnaires (Fadele, 2011).

\subsection{Method of Data Collection}

The questionnaire were administered to the respondents during school hours, they were given the questionnaire and guided on how to fill it. The students were encouraged to fill in the correct and true information about them as the questionnaire does not contain any question that could reveal their identity. The data collected was analyzed using descriptive statistical analysis such mean, percentage, mode etc.

\subsection{DATA PRESENTAION AND ANALYSIS}

This section deals primarily with the presentation of the data collected as well as its analysis. The data collected was analyzed according to the five research questions earlier stated, using descriptive statistics. Table 1 shows the breakdown of the categories of respondents captured. A total of 121 students including science, commerce and art students were captured randomly from five senior secondary schools. Four questionnaires were invalid as a result of inappropriate filling of the questionnaire while 117 questionnaires were considered valid.

Table 1: Numbers of Respondents

\begin{tabular}{llll}
\hline Category of & No. of Questionnaires & Valid No. of
\end{tabular}




\begin{tabular}{lccc} 
Respondents & Administered & Questionnaires & Questionnaires \\
\hline Science Students & 61 & 58 & 3 \\
Art Students & 44 & 43 & 1 \\
Commerce Students & 16 & 16 & 0 \\
Total & 121 & 117 & 4 \\
\hline
\end{tabular}

\section{Responses on Research Question One}

The first question goes thus- What are the negative impacts of internet on student's performance? The results obtained for this question are presented in figures 1 and 2. Figure 1 shows the percentages of various utilizations of internet by the students. Figure 2 indicates the number of students in various class categories who engaged themselves in internet chatting.

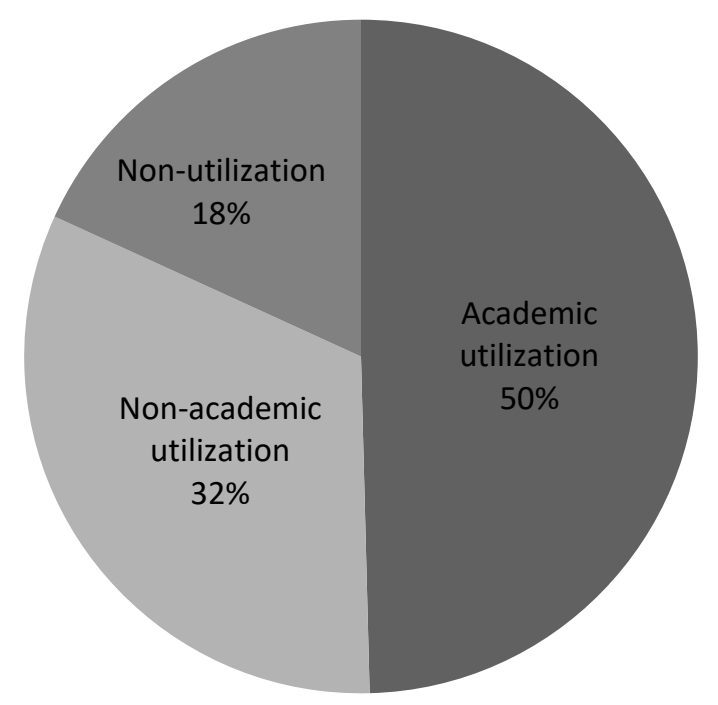

Figure 1: Purpose of internet browsing 


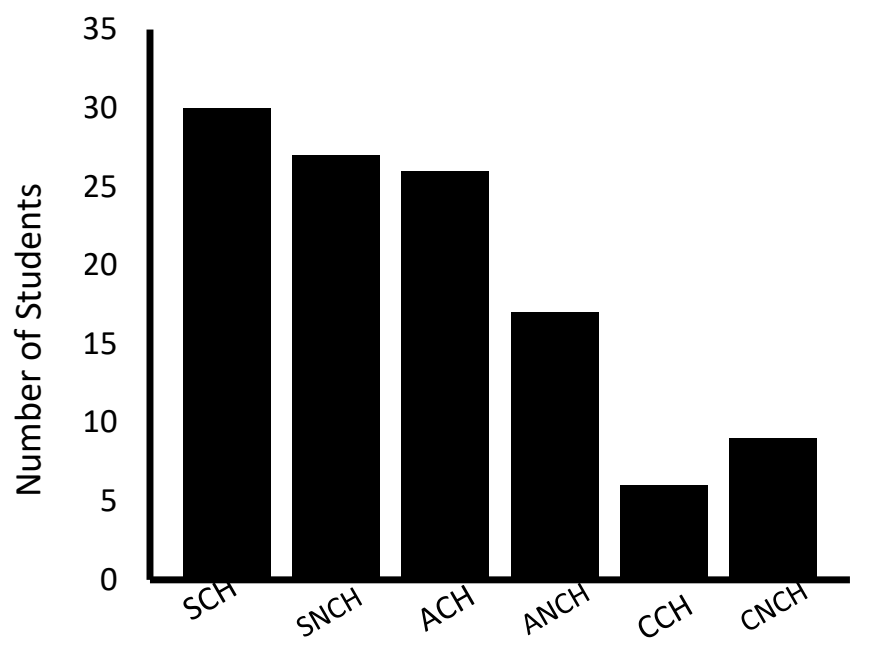

Class Categories
SCH-Science students who chat on the internet

SNCH- Science students who don't chat on the internet

ACH- Art students who chat on the internet

ANCH- Art students who don't chat on the internet

CCN- Commerce students who chat on the internet

CNCH-Commerce students who don't chat on the internet

Figure 2: Chatting on the internet

\section{Responses on Research Question Two}

The second question goes thus- What are the positive influences of internet on student's performance? The results obtained for the positive impact of internet on students' performance are depicted by figures 3,4 and 5 .

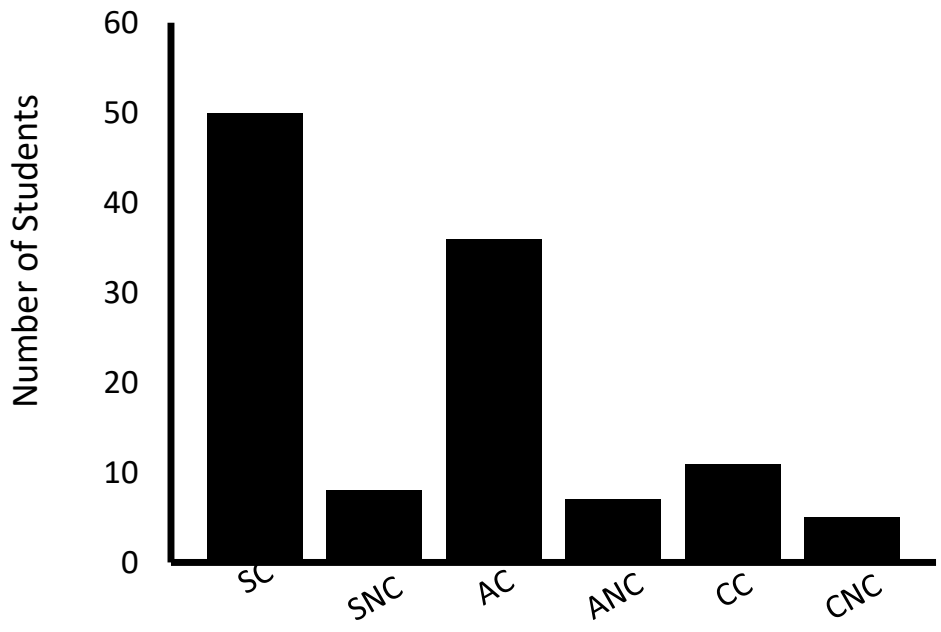

Class categories of students
SC- Science students who are computer literates

SNC- Science students who are not computer literates

AC- Art students who are computer literates

ANC- Art students who are not computer literates

CC- Commerce students who are computer literates

CNC-Commerce students who are not computer literates

Figure 3: Students' capability to operate a computer 


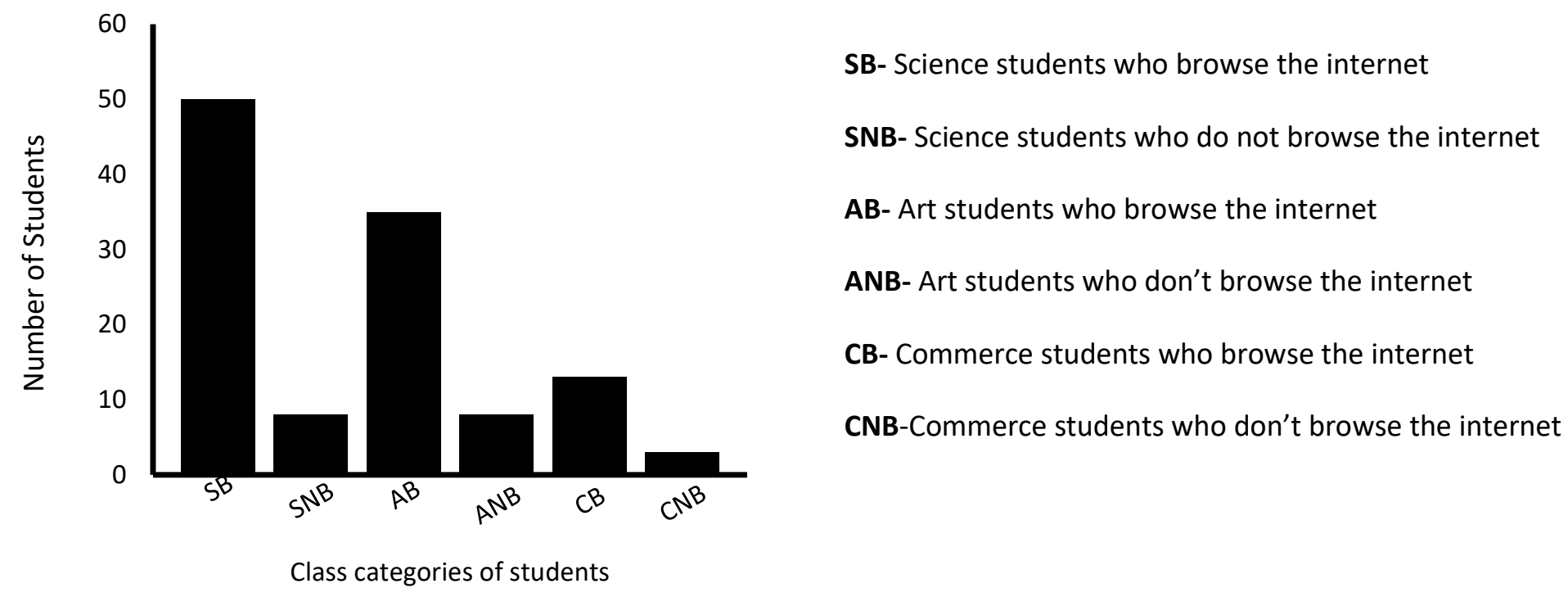

Figure 4: Students' capability to browse the internet

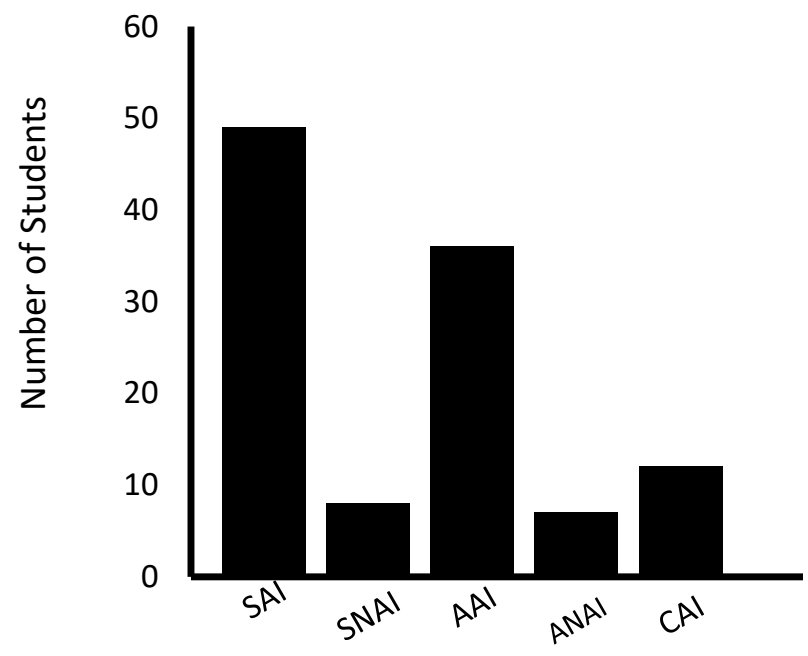

Class Categories
SAI- Science students who solve assignment from the internet SNAI- Science students who don't solve assignment from the internet

AAl- Art students who solve assignment from the internet

ANAI- Art students who don't solve assignment from the internet

CAI- Commerce students who solve assignment from the internet

CNAI-Commerce students who don't solve assignment from the internet

Figure 5: Utilization of internet in solving assignment

\section{Responses on Research Question Three}


The third question goes thus- What are the negative impacts of television on student's performance? The results obtained for the negative impacts of television on students' performance are depicted by figures 6 and 7.

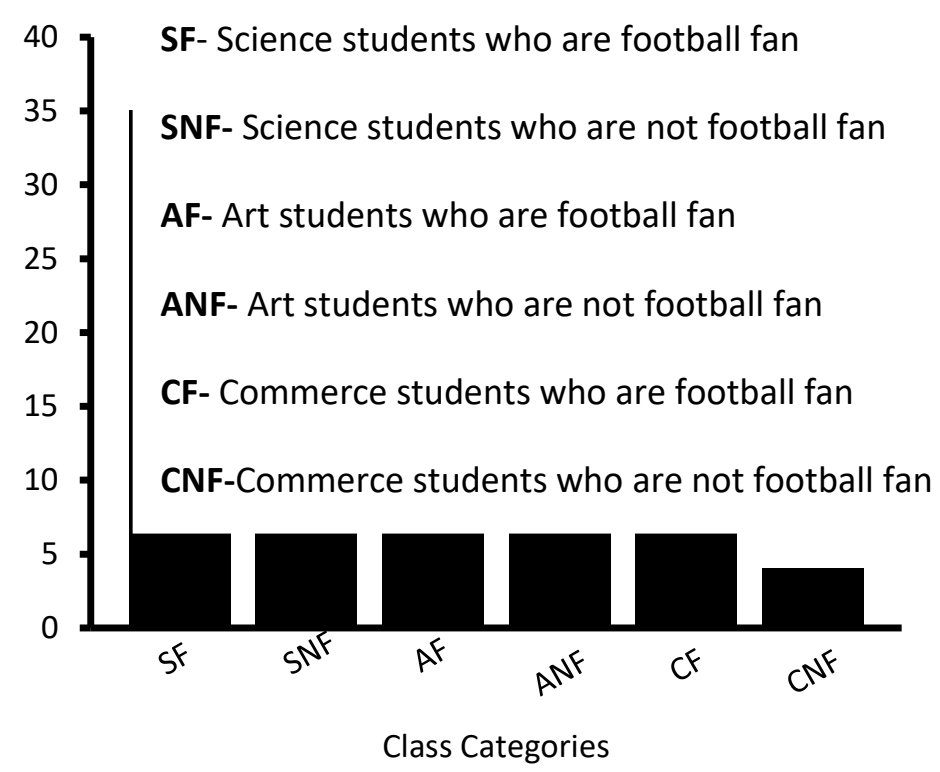

Figure 6: Students' disposition towards football viewing 


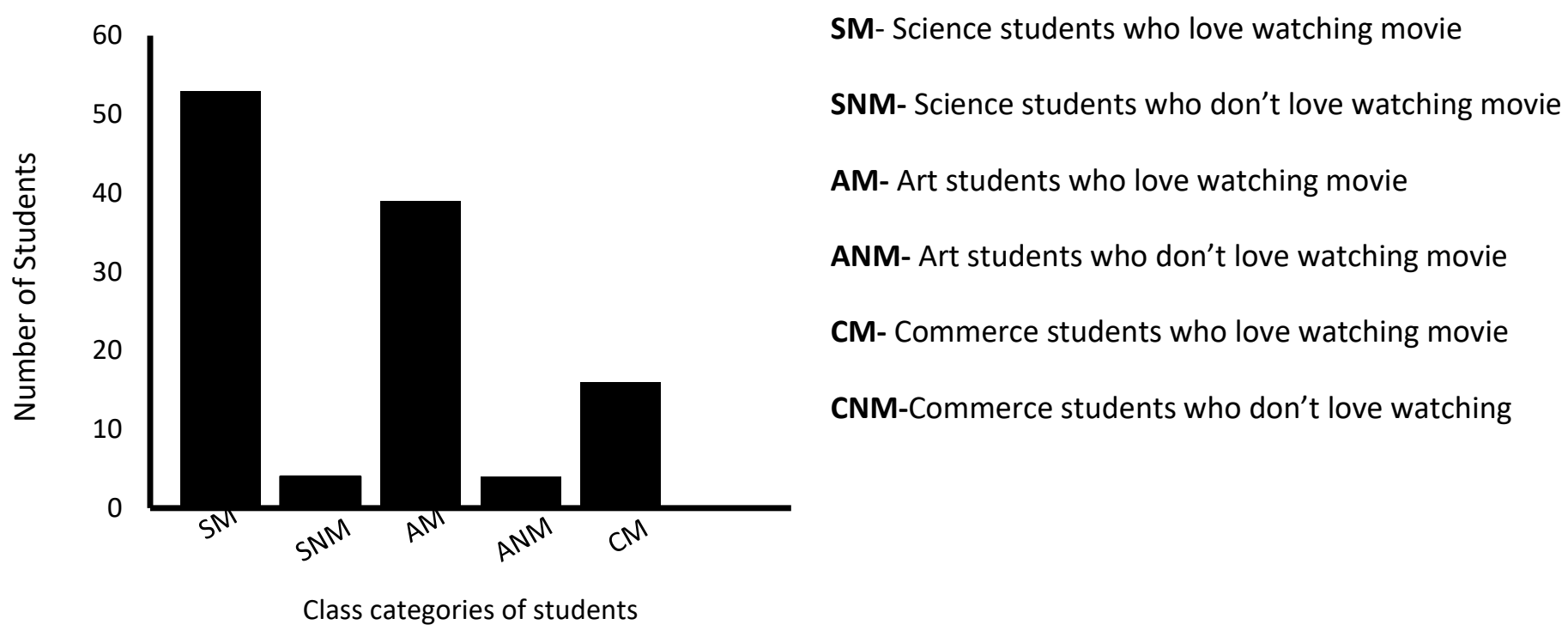

Figure 7: Students' disposition towards movies viewing

\section{Responses on Research Question Four}

The fourth question goes thus- How does television improve student's performance? The results obtained for the means through which television improves students' performance are depicted by figures 8 and 9 .

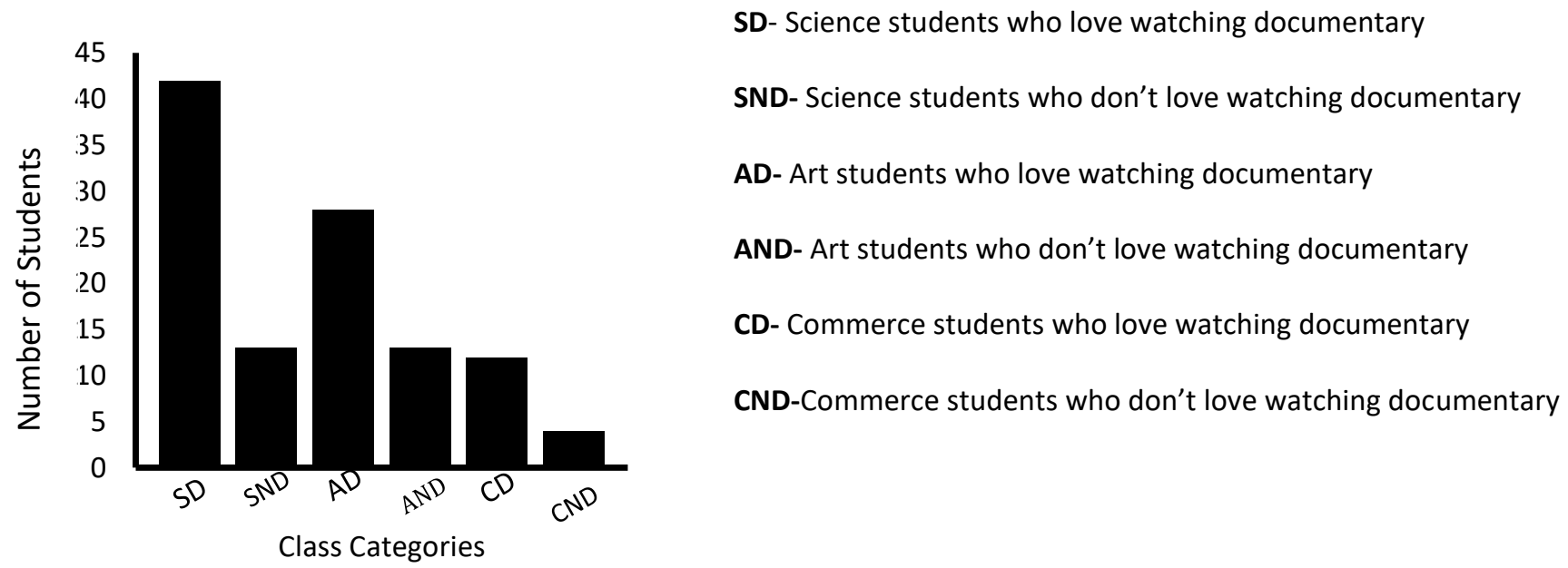

Figure 8: Students' disposition towards documentary viewing 


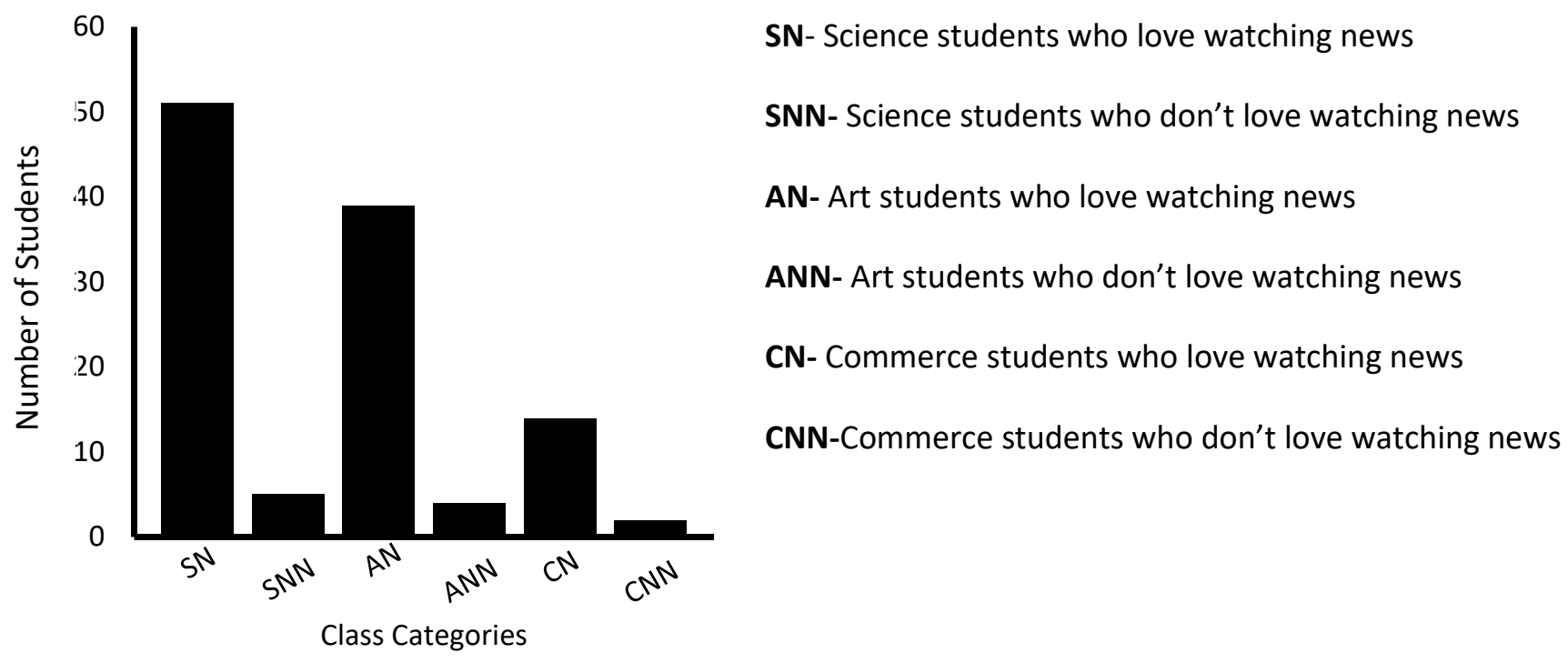

Figure 9: Students' disposition towards news viewing

\section{Sensitization on Utilization of Internet and Television for Academic Purposes}

The results obtained on availability and utilization of television and computers with internet facility is depicted by Tables 2 and 3. This proffers answers to question five which is -How can the students be sensitized on use of internet and television for academic purposes? It is very important to know whether televisions and computers with internet facility are available in schools before coming up with the idea of sensitizing schools about the positive use of television and internet facility. 
Table 2: Availability and Utilization of Computers with Internet Facility in Secondary Schools

\begin{tabular}{clll}
\hline Schools & Computer & Application & Internet Facility \\
\hline A & Available & For learning & Available \\
B & Available & For learning & Available \\
C & Available & Not for learning & Not available \\
D & Not available & Not applicable & Not available \\
E & Available & For learning & Not available \\
\hline
\end{tabular}

Table 3: Availability and Utilization of Television in Secondary Schools

\begin{tabular}{llll}
\hline Schools & Television & Video CD Player & Application \\
\hline A & Available & Available & for entertainment \\
B & Not available & Not applicable & Not applicable \\
C & Not available & Not applicable & Not applicable \\
D & Not available & Not applicable & Not applicable \\
E & Not available & Not applicable & Not applicable \\
\hline
\end{tabular}

\subsection{DISCUSSION}

This section presents and discusses the results obtained from the analysis of data derived from the findings of this research. It also shows the summary and conclusion as well as 
recommendation. It is stated at the opening chapter of this research that this study investigated the effects of internet and television on the performance of senior secondary school students. This was further addressed by stating some pertinent questions in order to discover and establish the effects of internet and television on students' performance. Each of these questions would be examined and discussed as follow with the viewing of proffering answers to them.

The results from the first research question showed that $50 \%$ of the total number of respondents applied internet for academic purposes while $18 \%$ of the students does not know how to browse the internet and $32 \%$ of the respondents applies internet for non-academic purposes as shown in figure 1 in the previous chapter. It was discovered that most of these students browse the internet at their own expense since Internet facilities are not available in most schools. Moreover, from the result, good proportion of the respondents from all class categories spends their time chatting on the internet on information irrelevant to academic development. It has been discovered that students can easily be influenced adversely through activities such as chatting on the internet. Brown and Marin (2009) showed a relative relationship between exposure through video games or the Internet to adolescent smoking and drinking behaviors. All these behaviors could have drastic impact on performance of students in schools. It was also observed that most students browse the internet without being monitored by the parents or teachers; this gives room for students to do whatsoever they want to do on the internet. Subrahmanyam et al., (2000) reported surveys of parents suggest that they buy home computers and subscribe to Internet access to provide educational opportunities for their children and to prepare them for the "information age." Although they are increasingly concerned about the influence of the Web on their children and are disappointed with some of the online activities their children engage such as games and browsing the Internet to download lyrics of popular songs and pictures of rock stars. However, research on 
the adverse influence of Internet utilization by secondary school students is still sketchy and ambiguous, some initial indications of negative effects are beginning to emerge. In Nigeria, it has been discovered that the standard of education is falling both at primary and tertiary levels. This has become an issue of concern for stakeholders in education sector. This could be linked to the advent of information technology age as good percentage of these students engages themselves in browsing. There has been decline in the performance of students in public examinations such as West African Examination Council and National Examination Councils with rapid development in electronic media such as Internet. This indicated that performance of students is not only influence by political response, but also by abuse and mismanagement of internet facility. So also, some research has been done to date relating exposure through video games or the Internet to adolescent smoking and drinking behaviors (Brown and Marin, 2009).

However, the results from the second research question showed some glimpse of hope on benefits that can be derived from internet. It was observed that despite the adverse effects of internet on performance of students; the performance of some students has been improved through exposure to internet. This depicts the positive influences of internet on students' performance. Figure 3 shows that higher proportion of the students could operate a computer especially science and art students with the commercial students being the least. Students' capability to browse the internet followed the same trend as their capability to operate a computer according to figure 4 . The science students mostly solved their assignment on the internet, as seen in figure 5. It was observed that most students who could browse, could also operate a computer. This could be as a result of their interest in browsing the internet. Even though, positive effect of internet browsing on performance of students in Rigachukun inspectorate is not really glaring. However, if the use of internet by secondary school students is properly regulated and monitored, there would be 
significant improvement on the performance of students. Subrahmanyam et al. (2000) showed that early home computer use by the high school student improves their dexterity in computer application; it was further revealed that computer use has been linked to improvements in general academic performance as well. This corroborate with some of the findings and observations about the performance of students in Rigachukun inspectorate.

Moreover, according to the results of the investigation it was asserted that, beside internet, television also has some adverse effects on the performance of student in Rigachukun Inspectorate. It was discovered that the number of students who are football fans were more than those who do not belong to any fan. This indicated the level of devotion of these students to television viewing. A football match lasts for minimum of about ninety minute and if a student watches two matches in a day, that means that he would spend more than three hours on television viewing. Besides football viewing, more than $80 \%$ of the student in Rigachukun inspectorate enjoys watching movies as shown in figure 7. A movie lasts for about two hours. A student watches two movies or film in a day would spend four hours on television viewing. Brown and Marin (2009) reported that children who watch excessive amounts of television have high propensity to score lower on standardized academic assessments than those who watch less television. However, it was shown that for factors like IQ and socioeconomic status, this relationship generally disappears. Observations on academic performance of some students in Rigachukun Inspectorate were very poor. This is in agreement with Brown and Marin (2009).

However, television could be utilized in improving the academic performance of students generally. A good number of the students captured in Rigachukun Inspectorate showed some interest in documentary and news viewing as shown in figures 8 and 9 respectively. Many researchers have shown that television is a potential educational tool if well harnessed and utilized 
positively (Achimugu et al., 2010; Siraj, 2008; Rauterberg, 2004). In the past some school used to organize videos on literary playlet for Literature in English students in order to prepare them for exams. Many students have testified to the fact that they learned most of their vocabulary from educative television programs. Achimugu et al. (2010) reported that educational television programs such as “Who Want to be a Millionaire”; Nigeria’s biggest thought provoking program, enlightens people because of the questions that are required to be answered before the cash price is awarded. Questions are drawn from all works of life ranging from religious, cultural, educational to contemporary issues, thereby facilitating the acquisition of basic skills amongst populace. This indicates that television is a potent tool for learning in secondary school.

Having discovered that television and internet are popularly used by students of senior secondary schools in Rigachukun Inspectorate. Tables 2 and 3 show the availability and utilization of television and internet in senior secondary school in Rigachukun Inspectorate. In most of these schools computers are used for learning purpose, with internet access being available in few of them. However, television is not available in most schools; it is hardly used for educational purpose where it is available. It has been observed that television is used for entertainment in schools where it is available; it is not often used for academic purpose. It has been asserted that television and internet are potent tools for educational development. The performance of students in public examination can be improved by introduction of television and internet to schools as tools for learning. This will involve sensitization and training of teachers and students on utilization of internet and television for academic purpose. So also, since most students have interest for television programs and internet, it will not be difficult to apply these tools in learning process.

The findings of this research are summarized and highlighted as follow: 
1. The percentage of senior secondary school students who made use of internet for academic purpose is as much as those who could not operate a computer or even browse the internet.

2. Good number of students applied internet mostly through phones and computer in solving their assignment; however with little or no improvement in their academic performance. In this case the effect of internet on academic performance is viewed as being obscuring.

3. A larger percentage of students devoted their time to watching non-educative programs on television; thus affecting the academic performance of students.

4. Some of the students who watch non-educative programs also have interest in watching educational programs on the television.

5. Investigation carried out revealed that students in senior secondary school need sensitization and orientation on how they can derive the best from internet and television. Schools should also be encouraged in using television as an instrument of learning and teaching.

\section{CONCLUSION}

Television and internet are very important tools which are mainly applied in dissemination of information in the society. It is a very important social media through which a lot has been achieved. Investigations have revealed that television and internet could be used in improving the academic performance of students in senior secondary schools. It is very important to educate student on the downside of engaging themselves in non-educative activities on the internet and television. Students should be sensitized and orientated on how they can derive the best from the internet and television. 
Brown and Marin (2009) stated that future research will need to better investigate how these increasingly integrated media (television, Internet, computers, cell phones) shape the lives of adolescents, and how the media can be used to actively shape health and development in positive ways. As a result this brought about this research. It is recommended that further study and investigation should be carried out with a view to covering more inspectorates in Kaduna state. Future research will need to investigate television programs that facilitate learning as well as internet websites that encourages learning.

\section{REFERENCES}

Achimugu, P.; Oluwagbemi, O. and Adeniran, O. (2010). An Evaluation of the Impact of ICT Diffusion in Nigeria's Higher Educational Institutions. Journal of Information Technology Impact. Vol. 10 (1):25-34.

Anderson, D., Huston, A., Schmitt, K,., Linebarger,D., \& Wright, J. (2001) Early Childhood television viewing and adolescent behaviour Monographs of the Society for Research in Child Development, 66, 1.

Brown, B. and Marin, P. (2009). Adolescents and electronic media: growing up plugged in. Child Trend Research Brief. National Adolescent Health Centre. 29:1- 13.

Blurton, C.(2002).“New Directions of ICT Use in Education”. Available online http://www.unes co.org/education/ educprog/lwf/dl/edict.pdf; accessed 7 August 2002.

Escobar-Chavez, S.L., and Anderson, C. (2008). Media and risky behaviors. Future of Children. Vol 18, no 1, 147-180. 
Fadele, O.K. (2011). Effects of television and internet browsing on senior secondary school students in Rigachukun inspectorate of Kaduna state. An unpublished PGDE thesis. National Teachers’ Institute Kaduna Nigeria.

Federal Ministry of Education, (2005). Nigeria Education Sector Diagnosis (A Condensed Version). A Framework for Re-engineering the Education Sector. Education Sector Analysis Unit.

Huston, A., Anderson, D., Wright, J, Linebarger, D., Schmitt, K (2001) 'Sesame Street viewers as adolescents: The Recontact Study. In S. Fisch and R. Truglio (eds), “G” is for "growing: Thirty years of research on children and Sesame Street, pp. 131-144: Mahwarh, NJ: Lawrence Erlbaum Associates.

Huston, A., Bickham, D., Lee, June, Wright, J (2007) 'From Attention to Comprehension: How children watch and learn from television' in N. Pecora, J. Murray and E. Wartella (eds) Children and Television: Fifty Years of Research. Mahwah, New Jersey: Lawrence Erlbaum, pp. 41-63.

Kaiser Family Foundation (2006). The Media Family: Electronic Media in the Lives of Infants, Toddlers, Preschoolers and their parents, May 2006, Menlo Park, California.

Kondo, K and Steemers, J. (2007). Can Television be Good for Children? The Communication and Media Research Institute. University of Westminster. pp:1 - 22.

Lemish, D \& Rice M., (1986) Television as a talking picture book. A prop for language acquisition. Journal of Child Language, 13, 251-74. 
Nwaoko, S. (2012). Paediatrician advocates telemedicine to tackle rural health problems. The Nation Newspaper. 22 March 2012.

Osunade, O. (2003). An evaluation of the impact of internet browsing on students' academic performance at the tertiary level of education in Nigeria. Educational Research network for West and Central Africa (ERNWACA). pp:5 - 31.

Rauterberg, M. (2004). Positive effects of entertainment technology on human behavior. Building the Information Society. Kluwer Academic Press. pp. 51-58.

Robert P. H. and Suzanne P. (1982). Television influence on social reality in television and behaviour: Ten Years of Scientific Progress and Implications for the Eighties, ed. National Institute of Mental Health, Vol. 2 Rockville, MD: US National Institute of Mental Health, 1982: 224-47.

Siraj, S.A. (2008). Suitability of aiou television and its impact on students' achievements. Turkish Online Journal of Distance Education. Vol. 9(3):99- 111.

Subrahmanyam,K.; Kraut, R.E.; Greenfield, P.M. and Gross, E.F. (2000). The impact of home computer use on children's activities and development. The Future of Children. (Children and Computer Technology) Vol. 10(2): 123 - 144.

The Commonwealth Learning (2002). An Introduction to Open and Distance Learning. available from http://www.col.org/ODLIntro/introODL.htm; accessed 14 August 2002.

Wilson, B. (2008). Media and children's aggression, fear, and altruism. Future of Children. Vol. 18, no 1, pp 87-118. 
Wolak, J., Mitchell, K. and Finkelhor, D. (2007). Does online harassment constitute bullying. An exploration of online harassment by known peers and online-only contacts. Journal of Adolescent Health. 41:S51-S58. 